\title{
THE WINDOW INFORMATION FOR INVESTOR ON ACCOUNTING PROFIT FORECASTING
}

\author{
Ratna Wijayanti Daniar Paramita ${ }^{1)}$
}

1) STIE Widya Gama Lumajang, Indonesia

E-mail: pradnyataj@gmail.com

\begin{abstract}
This study aimed to obtain empirical evidence, examine and explain he factors (leverage, persistence, growth, size and beta) that affect informativeness of earnings and its application in the financial statements at Manufacturing Companies listed in the Indonesia Stock Exchange 2013-2016. Research on the relationship between stock returns within come to determine the extent of their relationship are many who use earnings figures as the dependent variable regressed with stock returns as the independent variables are calculated by different methods. This method measures the magnitude of abnormal stock returns in response to the expected components of a company's reported earnings by using Earning Response Coefficient (ERC). Plan for data analysis in this study will be conducted using Path Analysis with analysis application of Moment Structure (AMOS).Conclusions of this study is significant influence of Leverage, Persistence profit and growth to Informativeness of earnings, either directly or through intervening variables Size and Beta.
\end{abstract}

Keywords: Informativeness of Earnings, leverage, persistence, growth

\section{Introduction}

Market the oryofefficient explained that investors react immediately to new information coming in the market, which caused the stock price to make adjustments. This means that both individual investor sand institutional investors always follow the information and price movements in the market. This happens because investors when their fund sista king into account the company's prospects both short term and long term.

Investors have confidence in the beginning of the expected return and risk of the company long before the financial statements reissued. Event he forecast period can be up to 1 year until shortly before submission of financial statements. A head of there lease times of financial reports, investors have more information to analyze the accounting profit. Atthetime the company announced financial reports, there will be good news or bad news. If there ported accounting profit was higher than forecast investor then there is good news, so for then extinvestor will revise upwards the company's profit forecast. Conversely, bad news can happen if the accrual of reported earnings lower than the predictions of investors, which led investors to revised ownan dislikely to sell share soft he company. 
Theoretically volume of shares will be greatly affected immediately after the company reported its financial statements. When that happens is good news investors will buy shares of the company, resulting in stock price will rise, and in case of bad news investors will sell shares in the company so that the stock price will go down. The rise and decline of the stock price will accumulation commulative abnormal return (CAR) on each company.

Informativeness of earnings is on method used to use the earnings figures as the dependent variable is regressed with stock returns as the independent variable. This method measures them magnitude of abnormal stock returns in response to the expected component sofa company's reported earnings by using Earning Response Coefficient (ERC) Scott (2010:154). Balland Brown (1968) in his study found a significant relationship between the information during the announcement of the company's profit with the stock price movement. Their research explain changes in stock prices move in line with changes in accounting earnings and investor prediction. This means that if the investor predicts company profit share price will rise, where a sift he predictions of investor so the rise then the stock price will move down.

Research on the relationship between stock returns within come to determine the extent of their relationship are many who use earnings figures as the dependent variable regressed with stock returns as a variable independent hat calculated by different methods. The problem in this study is what hero the method also can be used to profit measure, namely by using variables informativeness of earnings may indicate that the profit has information content which his reflected in the stock price.

Some researchers who tested Earning Response Coefficient (ERC) try hooking Earning Response Coefficient (ERC) with other factors such as size Earning Response Coefficient (ERC) (Eastonand Zmijewski, 1989) and Leverage by Earning Response Coefficient (ERC) (Dhaliwaletal, 1991), (SriMulyani, 2003). Langand Lundholm (1993) examined the factors affecting the level of disclosure found that companies that have a low correlation of returns and earnings more disclosure, in other words Earning Response Coefficient (ERC) negatively related to the disclosure. Murwaningsari (2008) and Paramita (2011) examined the path analysis, using voluntary disclosure as an intervening variable.

The purpose of this study is to get empirical evidence, examine and explain the factors (capital structure, the persistence of earnings and growth) which influence the informativeness of earnings the Size and Beta as an intervening variable the Manufacturing Company listed on the Indonesia Stock Exchange.

\section{The Theoretical FrameWork and Development Hypothesis}

Scott (2000) states that the company has many contracts, for example, the employment contract between the company and its managers and the loan contract between the company and its creditors. The employment contract in question is a contract between the owners of capital to the company manager. Where between the agent and the principal wants to maximize the utility of each with the information held. But on the one hand, agents have more information (full information) compared with the principal on the other side, causing the asymmetry information. More information is owned by the manager may trigger oper for mactions in accordance with the wishes and interests to maximize utility his. As for the owners of capital in this case the investor, it would be difficult to effectively control the actions taken by management because it has little information exists. Therefore, sometimes the specific policies carried out by the management company without the knowledge of the owner or investor capital.

Signaling theory address issues Asymmetry information. The theory is based on the premise that managers and share holders do not have the same access to company information. No 
specific information known only to the managers, while share holders do not know that information. So, there is information asymmetry (asymmetricinformation) between managers and share holders. Asaresult, when acompany's capital structure changes, it can bring information to share holders which would result in the value of the company changed. In other words, going on a signor signal (signaling).

The hypothetic theory underlying the semi strong market hypothes is about the information value relevance earnings (earnings announcements influence there action of investors). Value relevance profit information proving that earning squality is known of it simpact on investor reactions are described in the stock price. The greater the profit the investor reaction will be higher. The quality of earning scan be indicated as the ability of earnings information to respond to the market. In other words, earnings are reported to have a response force (power of response).

To measure the value relevance information to determine the relationship of profit or earnings to stock returns can use the method Informativeness of earnings. While one of the measurement or proxy is used to measure the quality of earnings was Earning Response Coefficient (ERC). The strong market reaction to the earnings information reflected in the high Earnings Response Coefficients (ERC), which shows the quality of reported earnings (Collinsetal.1984).

Choand Jung (1991) classifying the theoretical approach Earning Response Coefficient (ERC) into two groups: (1)assessment model based on economic information (information economic based valuation model) as developed by Holthausenand Verrechia (1988) and Lev (1989) which in dicates that the strength of investor response to the information signal gain is a function of the uncertainty in the future. The greater the no is eint he corporate reporting system (the lower the quality of earnings), the smaller Earning Response Coefficient (ERC) and (2) assessment model based on time series earnings (time series based valuation model) as developed by Beaver, Lambert and Morse (1980). Beaver (1968) defines, Earning Response Coefficient (ERC) or the earnings response coefficients the slope coefficient on earnings. Earnings response coefficients measure the strength of the stock price in response to the accounting profit. Coefficient accounting profit may indicate the quality of corporate profits.

Capital Structure Theory

Capital structure theory to explain the influence changes in capital structure to the company's value, if investment decisions and dividend policy are held constant. The capital structure is best for the company's high grow thrate is different from the company's grow thrate is low. Companies with a high grow thrate, in conjunction with leverage, you should use debt as a source offinancing in order to avoid the cost of agency (agencycost) between share holders with the company's management, otherwise the company with a low grow thrate should use equity as a source of funding for the use of debt will require the company to pay interest regularly.

According to Brigham and Houston (2001:14), Financial leverage (financial leverage) is a measure that indicates the extent to which the securities fixed income (debt and preferred stock) used in the structure of capital. Financial leverage shows the proportion of the use of debt to finance investment, Leverage ratio is the proportion of total debt to equity share holders. The ratio is used to provide an overview of the capital structure of the company, so it can be seen the risk of non-collection of a debt.

Growth

Growth is a grow thrate above the normal rate of return, meaning that returns the same level of investment risk in the industry kompetetif. When the good news that is happening now in 
profit provide growth opportunities, the ERC will rise. Research to measure the growth opportunities for the relationship to the ERC conducted by Collins \& Kotari (1989) ; Palupi (2006); Pishgooii (2011); Hasanzade, Darabi \& Mahfoozi (2013); Aston, Wang(2013); A.Syukur \& Supriyanto (2014).

Size (Company Size)

In the study Fitriani (2001) there are three alternatives that are used to calculate the size of the company, ie total assets, net sales and market capitalization. In the study Fitriani(2001) company size measured by total assets, because he thinks the total assets of more shows company size compared to market capitalization.

Beta

For investors Current profit is an indicator of the company's ability to generate profits and future returns, the risk of future returns (beta), the lower the investor reaction to the unexpected earnings. This has been researched by Collins and Kotari (1989), Easton and Zmijewski (1989), Hasanzade, Darabi \& Mahfoozi (2013); A.Syukur \& Supriyanto (2014). Dhaliwal, Lee and Farger (1991) proved that Leverage negatively affect earnings response coefficients are Earning Response Coefficient(ERC). Companies that leverage its high level means having a greater debt than capital. Thus, if an increase in profits, the benefit is the debt holders, so the better the condition of corporate profits, the more negative the response of share holders, as share holders considered that such profits just hang creditors.

Murwaningsari (2008) revealed the size of the company (size) in the issue Earning Response Coefficient (ERC) is used as a proxy for the stock price informativeness. Research inserting variable size as a control variable. The results showed that the size of the company's significant negative effect on Earning Response Coefficient (ERC). The larger the size of the company will have more information than a small company. The results of this study support Chaney and Jeter (1991) and Collinsand Kothari(1989).

Hypothesis Development in this research:

Hypothesis 1: Leverage has an influence on Informativeness of earnings

Hypothesis 2: Persistence earnings have an influence on the informativeness of earnings

Hypothesis 3: Growth have an influence on the informativeness of earnings

Hypothesis 4: Leverage has an influence on Informativeness of earnings through size

Hypothesis 5: Persistence earnings have an influence on the informativeness of earnings through Beta

Hypothesis 6: Growth have an influence on the informativeness of earnings through Beta

In summary the conceptual framework for the informativeness of earnings, can be seen in Figure 1.

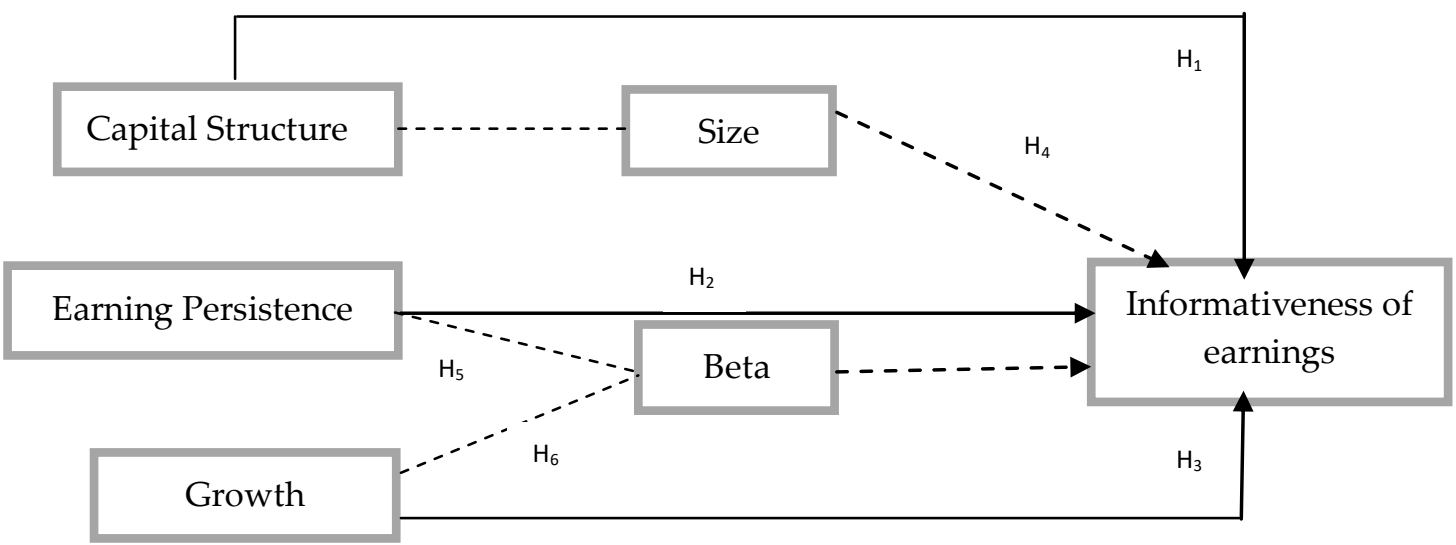

Fig. 1 Conceptual Framework 


\section{Research Methods}

Structural Equation

Hypothesized structural equation is as follows:

IE $=\beta_{0}+\beta_{1}$ Lev $+\beta_{2}$ Persisten $+\beta_{3}$ Growth $+\beta_{4}$ Size $+\beta_{5}$ Beta $+\varepsilon_{i t}$

Size $=\beta_{0}+\beta_{1}$ Lev $+\varepsilon_{\text {it }}$

\section{Beta $=\beta_{0}+\beta_{2}$ Persisten $+\beta_{3}$ Growth $+\varepsilon_{\text {it }}$}

Inthiscase:

$$
\begin{array}{ll}
\text { IE }_{i t} & =\text { Coefficient response to the company's profit in period } t \\
\text { LEV }_{\text {it }} & =\text { Leverage firm } \mathrm{i} \text { in period } \mathrm{t} \\
\mathrm{EP}_{\mathrm{it}} & =\text { Persistence of earnings the company } \mathrm{i} \text { in period } \mathrm{t} \\
\text { Growthit } & =\text { Growth company } \mathrm{i} \text { in period } \mathrm{t} \\
\text { Size }_{i t} & =\text { Magnitude of firm } \mathrm{i} \text { in period } \mathrm{t} \\
\text { Beta } & =\text { Beta firm } \mathrm{i} \text { in period } \mathrm{t} \\
\varepsilon_{\mathrm{it}} & =\text { Componenterrorfirmiinperiod } \mathrm{t}
\end{array}
$$

\section{Population and Sample Research}

The study population includes all companies listed on the Indonesia Stock Exchange by using purposive sampling method. Companies sampled must meet the following criteria:

1) Companies whose shares are actively operating from 2013 until December 2016, and to publish audited financial statements on a regular basis.

2) The Company did not experience losses during the estimation period

3) Has the complete data is used as a variable in this study and is consistently reported at BAPEPAM.

Operational Variables

Leverage Variable

Leverage is calculated using the formula Debtto Equity Ratio (DER), which compares the total debt to total capital itself (Dhaliwal: 1991).

EarningsPersistenceVariable

Variable earnings persistence in this study developed by Scott (2003) and Kormendi \& Lipe, 1987, with the following formula:

$$
\begin{array}{ll}
\text { In this case: } & \text { Xit }=\alpha+\beta \text { Xit }-1+\varepsilon 1 \\
\text { Xit } \quad=\text { The company's profit in year } \mathrm{t} \\
\text { Xit-1 } \quad=\text { Earnings firm I yeart-1 } \\
\beta \quad=\text { Persistence of earnings } \\
\varepsilon \quad=\text { Component error }
\end{array}
$$

\section{Growth Variable}

Growth variables in this study using the Marketto Book Ratio is calculated by comparing market capitalization to Book Value of Equity (Collins and Kothari, 1989).

Variable Size (Scale Company)

Company size was measured by using anatural log (Ln) total assets (Jogiyanto, 2000)

Beta Variable

Beta is a systematic enterprise risk estimated by using a market model CAPM formula:

$$
\mathrm{R}_{\mathrm{it}}=\alpha_{\mathrm{i}}+\beta_{\mathrm{i}} \mathrm{R}_{\mathrm{mt}}+\varepsilon_{\mathrm{i}}
$$


In this case:

$R_{i t}$ is the return of i period $t$

$R_{m t}$ is the market return in period $t$

Variable Informativeness of Earnings

Variable informativeness of Earnings proxied by Earning Response Coefficient in this study was developed from models Cho and Jung (1991). Earnings Response Coefficient (ERC) will be calculated from slope $\alpha 1$ on EU relations with the CAR after the controlled annual Return.

$$
\mathrm{CAR}_{\mathrm{it}}=\alpha_{0}+\alpha_{1} \mathrm{UE}_{\mathrm{it}}+\alpha_{2} \mathrm{R}_{\mathrm{it}}+\varepsilon_{\mathrm{it}}
$$

In this case:

$\mathrm{CAR}_{\text {it }}=$ The cumulative abnormal return for firm i during the observation period \pm 5 days from the publication of financial statements

UEit $\quad=$ Unexpected earnings

$\mathrm{R}_{\mathrm{it}} \quad=$ Annual return

$\varepsilon_{\text {it }} \quad=$ Error component in the model of the company $\mathrm{i}$ in period $\mathrm{t}$.

The $\alpha_{1}$ value for each sample is the value of the ERC, which is different for each company (Time series model)

\section{Technical Data Analysis}

Technical analysis data in this research will performed using Pathanalysis with Analysis of Moment Structures (AMOS) software. In this study, conducted through direct testing and it indirectly on the dependent variable.

1. Testing directly between leverage, earnings Persistence and Growth against Informativeness of Earnings.

Testing hypotheses using pathanalysis to determine the simultant relationship of the variables tested. Relationships theoretical phenomenon, empirical research and development of hypotheses can be seen from the path diagram. P-value in this study using a level of significant $5 \%$ (alpha 0.05). In the process of testing the hypothesis if p $>0.05$ means that the hypothesis has any realor significant influence between the variables in the hypothesis, and vice versa.

2. Testing Indirect among Leverage, profits Persistence and Growth against Informativeness of Earnings the Size and Beta as an intervening variable

In the intervening testing, basic decision is to compare the coefficient indirect effect coefficient of direct influence. Coefficient direct influence of two variables in the table multiplied Standardiedz Direct Effect. Then the results will be compared, if the coefficient indirect effect (Indirect Effect) greater than/ equal to than the direct influence coefficient (Direct Effect), then the variables tested an intervening variable, and vice versa. 
Jurnal Terapan Manajemen dan Bisnis

Volume 3 Number 2 October 2017. Page 193-204

e-ISSN: 2477-5282

Results and Discussion

Research result

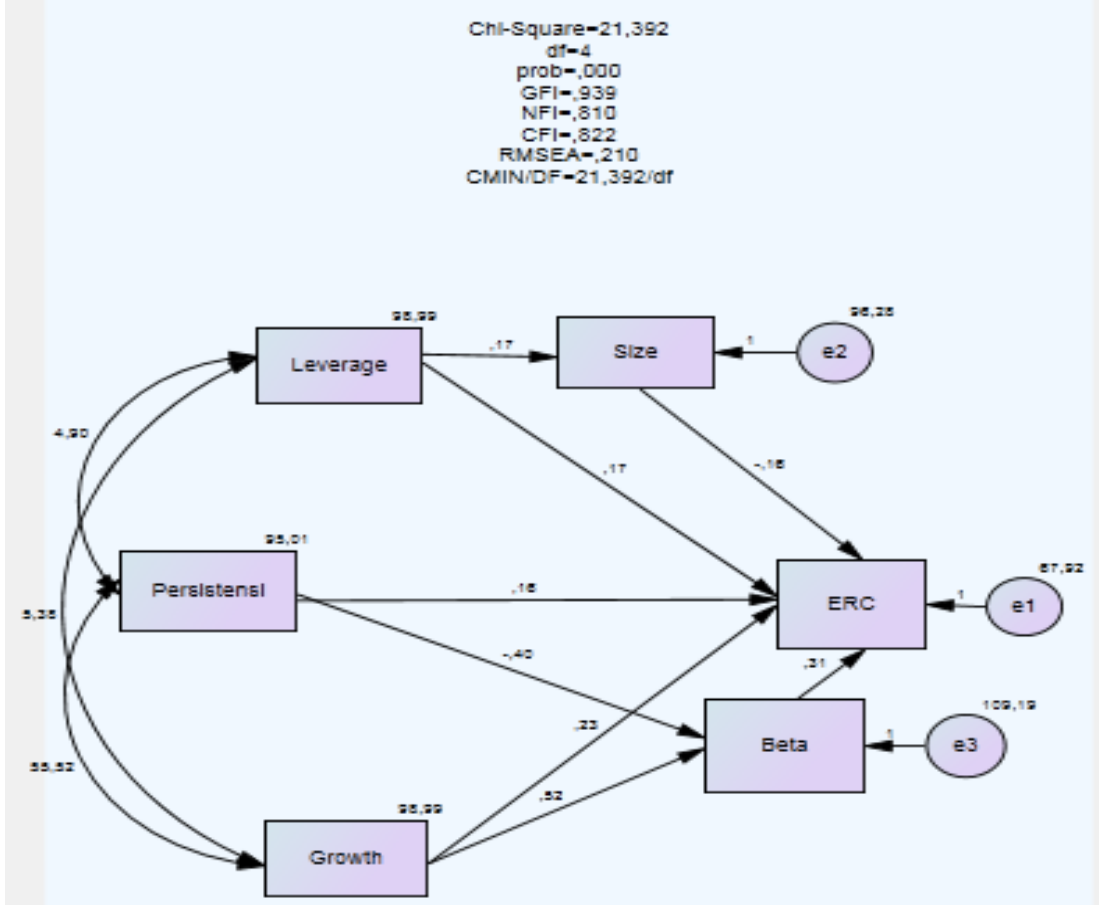

Fig. 2 Path Diagram

RegressionWeights:(Groupnumber1-Defaultmodel)

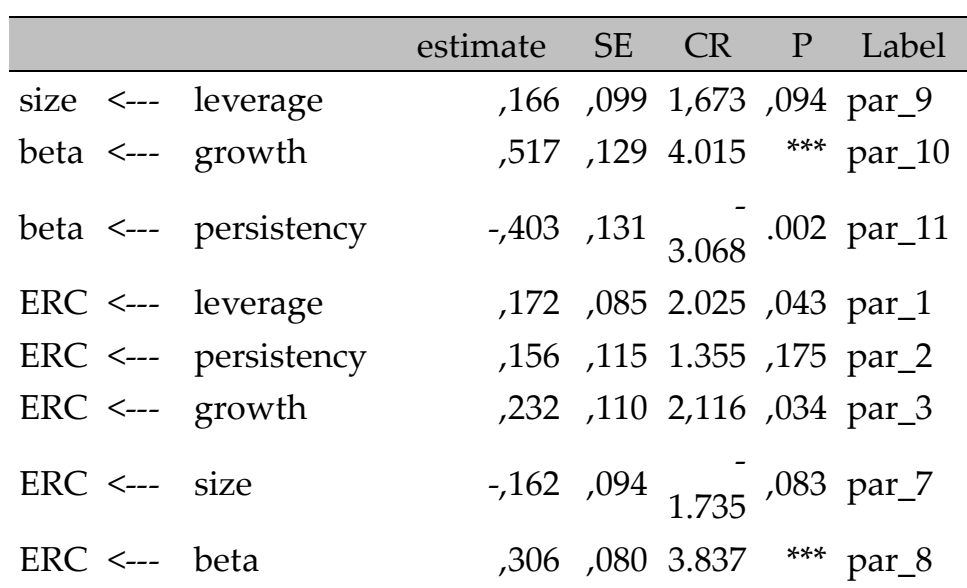

Standardized Direct Effects (Group number 1 - Default model)

\begin{tabular}{lrrrrr}
\hline & growth & persistency & leverage & beta & size \\
\hline beta &, 455 &,- 347 &, 000 &, 000 &, 000 \\
size &, 000 &, 000 &, 166 &, 000 &, 000 \\
ERC &, 231 &, 152 &, 171 &, 346 &,- 162 \\
\hline
\end{tabular}

Standardized Indirect Effects (Group number 1 - Default model) 


\begin{tabular}{lrrrrr}
\hline & growth & Persistency & leverage & beta & size \\
\hline beta &, 000 &, 000 &, 000 &, 000 &, 000 \\
size &, 000 &, 000 &, 000 &, 000 &, 000 \\
ERC &, 157 &,- 120 &,- 027 &, 000 &, 000 \\
\hline
\end{tabular}

There Effect Leverage Against informativeness of Earnings

Leverage ratio is the proportion of total debt to equity share holders. The ratio is used to provide an overview of the capital structure of the company. The survey results revealed that there is significant influence between Leverage Informativeness of Earnings. This can be seen from the probability value (p-value) of 0,043 .

Hypothesis testing results show there is the effect of variable leverage against Informativeness of Earnings, mean there are inter-relationship between the ratio of debt to ratio or the ratio between debt and equity with the response given by share holders on corporate profits. The capital structure of the company to give effect to share holders to respond to the company's reported earnings. This happens because the share holders or investors assume that the costs are relatively fixed interest rate to be paid to creditors, will affect the size of the profits (claims) for share holders.

Leverage ratio is the ratio of debt to equity and will move in tandem with the debt to equity if a company can use such assets, a higher return than the cost of debt, will increase the return on capital. If not, the company's debt sexceed assets, the cost of debt can be greater than the return on assets. In the long term, this will lead to bankruptcy. So investors should take this into consideration when investing in a company with a high leverage ratio, especially when the interest rate increases. So that the share holders of this will affect the profits will respond. Although debt holder received flowers are relatively fixed, however large or small acceptance of share holders to be obtained is the value after interest payments on debt to debt holder. The greater the interest paid each period it will further reduce corporate profits.

There Effect Persistency towards Earnings informativeness of Earnings

The results showed a significant difference between Persistency Against Earnings Earnings informativeness of use values with a p-value of 0,175. According to Scott (2009) more persistent, or permanent changes in earnings overtime, the higher the response to earnings. Profits of the enterprise maybe steadily increased or stable in the future. So the higher the market reaction to information that are expected to apply consistent (permanent) in the long term compared to the information that is temporary.

There Effect Growth towards informativeness of Earnings

The results showed that growth have a significant effect towards informativeness of Earnings. It is characterized by a probability value (p-value) of 0,0 to 34 , which means p-value below 0.05 .

Companies that have high growth response coefficient greater profit than the company that is experiencing low growth, consistent with the results of Collins and Kothari (1989) and Charitouetal (2001) who found a positive relationship growth (Growth) with ERC. Testing The Hypothesis Indirectly

As for testing the hypothesis indirectly or through intervening variables, can be seen in Table 2.

The results of hypothesis formulation indirectly 


\begin{tabular}{|c|c|c|c|c|}
\hline \multicolumn{2}{|c|}{ RelationshipsIndirect } & $\begin{array}{l}\text { Thecalculationresult } \\
\text { s }\end{array}$ & $\begin{array}{c}\text { Value } \\
* \text { ) }\end{array}$ & $\begin{array}{c}\text { Informatio } \\
n\end{array}$ \\
\hline $\begin{array}{l}\text { Leverage } \longrightarrow \\
\text { ERC }\end{array}$ & Size & $\begin{array}{l}(0,166)(-0.162)=- \\
0.027\end{array}$ & $\begin{array}{ll}- & 0.0 \\
27 & \end{array}$ & $\begin{array}{l}\text { significant } \\
\text { weak }\end{array}$ \\
\hline $\begin{array}{l}\text { Persistensi } \\
\text { ERC }\end{array}$ & Betar & $\begin{array}{l}(-0,347)(0,346)=0, \\
120\end{array}$ & $-0,120$ & $\begin{array}{l}\text { significant } \\
\text { strong }\end{array}$ \\
\hline $\begin{array}{l}\text { Growth } \longrightarrow \\
\text { ERC }\end{array}$ & Beta & $\begin{array}{l}(0.455)(0.346)=0 \\
157\end{array}$ & 0,157 & $\begin{array}{l}\text { significant } \\
\text { strong }\end{array}$ \\
\hline
\end{tabular}

Data Source: Data processed

*)Standardiedz Indirect Effect

Leverage has an influence on the informativeness of earnings through Size

Based on the results of the calculation of direct influence between variable leverage to variable Size $(0,166)$ and the direct influence of the variable size of the variable informativeness of earnings $(-0,162)$ the obtained results $(-0.027)$. The direct effect is shown in the results of standardized in direct effect to the effect of leverage on informativeness of earnings of- 0,027 . That is Size an intervening variable to an indirect relationship between the variables of the informativeness of earnings leverage. The coefficient of indirect -0.027 The values below 0.05 so that the indirect effect resulting weak.

Earnings persistence had an influence on the informativeness of earnings through Beta

Based on the results of the calculation of direct influence between variable to variable persistence Beta $(-0,347)$ and the direct influence of variables Beta against variable informativeness of earnings $(0,346)$ the obtained results $(-0,120)$. The direct effect is shown in the results of standardized indirect effect to influence persistency the informativeness of earnings of- 0,120 . That is Beta is an intervening variable for indirect relationships between variables The persistence of the informativeness of earnings. The coefficient of Indirect-0,120, the value is above 0.05 so that the indirect impacts generated strong.

Growth have an influence on the informativeness of earnings through Beta

Based on the results of the calculation of direct influence between variable to variable Growth Beta $(0,455)$ and the direct influence of variables Beta against variable informativeness of earnings $(0,346)$ the obtained results $(0,157)$. The direct effect is shown in the results of standardized indirect effect to influence Growth of the informativeness of earnings of 0,157 . That mean is Beta is an intervening variable for indirect relationships between variables Growth of the informativeness of earnings. The coefficient of indirect is 0,157 , the value is above 0.05 so that the indirect impacts generated strong.

\section{Conclusions, Implications and Limitations Research \\ Conclusion}

Conclusions of this study is not significant influence of Leverage, Persistence profit and growth to Informativeness of earnings, either directly or through intervening variables Size and Beta.

Implication

Results of research on Leverage, Persistence profit, growth, Size and Beta to Informativeness of earnings, it is relevant to encourage information presented can be useful for the analysis and investment decision making. The research will also provide benefits for 
researchers further examined and revealed other factors that could affect the Informativeness of earnings, either directly or indirectly.

Research limitations

This study did not consider the revents that have economic consequences, such as the distribution of dividends, mergers and changes in accounting policies. The events that led to the economic consequences affect informativeness of earnings proxied by Earning Response Coefficient (ERC) produced are not good enough for their compounding effect.

Research on the factors that influence the informativeness of earnings either directly or indirectly, has a lot of to do with the secondary data (quantitative), it is necessary also investigated factors informativeness of earnings in the qualitative way. It is with this in mind assume that investor or financier will provide a response to earnings areas a personisirrational, in addition, investors also often fused his/her personal identity into a collective identity. So the response of investors to the company's profit in turn is a manifestation of psychological condition of investors, not only because of the information (good news/ bad news) of the company's financial statements.

\section{References}

Adhariani. (2004) Tingkat Keluasan Pengungkapan Sukarela Dalam Laporan Tahunan dan Hubungannya Dengan Current Earnings Response Coefficient (ERC)". Jurnal Akuntansi dan Keuangan Indonesia. Vol 2, No.1 : 24-57.

Ainun dan Fuad Rachman. (2000) Analisis Hubungan antara Kelengkapan Pengungkapan Laporan Keuangan dengan Struktur Modal dan Tipe Kepemilikan Perusahaan. Jurnal Ekonomi dan Bisnis Indonesia. Vol. 115 No.I pp.70-82.

Ali, A. Dan P. Zarowin. (1992) Permanent vs. Transitory Components of Annual Earnings and Estimation Error in Earning Response Coefficients.Journal of Accounting and Economics, 15, 249-64.

Almilia, Luciana, dan Retrinasari, Ikka. (2007) Analisis Pengungkapan Karateritik Perusahaan Terhadap Kelengkapan pengungkapan dalam Laporan Tahunan Perusahaan Manufaktur Yang terdaftar di BEI. Proceding Seminar Nasional, Jakarta.

Ambarwati, Sri,. (2008) Earnings Response Coefficient (ERC). Akuntanbilitas, vol.7 no.2 hal:128134.

Beaver, W.R. Lambert dan D,. Morse. 1980. The information content of security prices. Journal of Accounting and Economics. 24 pp.3-37.

Beaver, W.H. Clark, R, W.F. Wright. 1979. The Association between unsystemic security returns and the magnitude of earning forecast error. Journal of Accounting Research. 17 pp.316-340.

Bringham, F Eugene and Joel F Houston. (2001) Financial Management. Edisi kedelapan, Jakarta. Erlangga.

Chandrarin, G., (2002) The Impact of Accounting Methods of Translation Gains (Losses) on the Earnings Response Coefficients. Proceeding Articles on SNA 5 24-35.

Chaney, P.K. dan D.C. Jeter, 1991, The Effect of Size on the Magnitude of Long Window Earnings Response Coefficients", Contemporary Accounting Research 8, No.2 : 540-560.

Cho, L.Y., and K. Jung. (1991). Earnings Response Coefficients: A Synthesis of Theory and Empirical Evidence. Journal of Accounting Literature, Vol.10. pp 85-116.

Cho, J.Y and K. Jung. (1991). Earnings Response Coefficient: A Sythesis of Theory and Empirical Evidence. Journal of Accounting Literature. 10: 85-116.

Dyer, J.C.IV. and A.J. McHugh,1975." The Timeliness Of The Australia Annual Report". Journal of Accounting Research. Autumn pp.204-220. 
Easton, P.D. dan M. Zmijewski. 1989. Cross-sectional Variation in the Stock Market Response to Accounting Earnings Announcements. Journal of Accounting and Economics 11:117141.

HolthausendanVerrechia (1988). The Effect of Sequential Information Release on The Variance of Price Changes In An Intertemporal Multi Assets Market. Journal of Accounting Research 26 (spring), pp.82-106.

Jensen-Meckling (1976)"The Agency Theory Of The Firm : Managerial Behavior, Agency Cost And Ownership Structure" Journal of Financial Economics $3: 305-360$.

Lang M dan R.J. Lundholm. 1993. Cross sectional determinants of analysist rating of corporate disclosure. Journal of accounting research, 31 : 246-271.

Lev (1989). On usefulness of earnings : Lesson ans directions from two decades of empirical research. Journal of Accounting Research 27 (supplement) pp. 153-192.

Lipe, R.C., 1990, "The Relations Between Stock Return, Accounting Earnings and Alternative Information", Accounting Review (Januari): 49-71.

Ferdinand, Augusty,. (2006) SEM Dalam Penelitian Manajemen. Edisi 2. FE-Undip.

Financial Accounting Standards Boards,. (2000) Statement of Financial Accounting Concept Number 2: Qualitatif Characteristics of Accounting Information. Stanford, Conecticut.

Fitriani. (2001) Signifikasi Perbedaan Tingkat Kelengkapan Pengungkapan Wajib Dan Sukarela Pada Laporan Keuangan Perusahaan Publik Yang Terdaftar Di Bursa Efek Jakarta. Makalah Simposium Nasional Akuntansi IV, Bandung. : Universitas Padjajaran dan Ikatan Akuntan Indonesia pp.133-154.

Gultom, Corry. (2008) Pengaruh kebijakan leverage, kebijakan deviden dan EPS terhadap nilai perusahaan pada perusahaan Manufaktur yang terdaftar di Bursa Efek Indonesia. Jurnal Akuntansi 47.

Horne, Jemes. (2005) Financial Manajemen, Prinsip-prinsip manajemen keuangan. Salemba Empat.

Jensen-Meckling. (1976) The Agency Theory Of The Firm : Managerial Behavior, Agency Cost And Ownership Structure Journal of Financial Economics $3:$ 305-360.

Keputusan Ketua Badan Pengawas Pasar Modal dan Lembaga Keuangan Nomor: Kep431/B1/2012 Tentang Penyampaian Laporan Tahunan Emiten atau Perusahaan Publik.

Meek, Robert dan Gray (1955) "Analisis Pengaruh Faktor-Faktor Fundamental Perusahaan Terhadap Kelengkapan Laporan Keuangan".

Mulyani, Sri., Nur F.Asik, dan Andayani,. (2007) Faktor-faktor yang mempengaruhi Earnings Response Coefficient (ERC) pada perusahaan yang terdaftar di BEI. JAAI vol.1, no.1 hal:35-45.

Murwaningsari, Etty. (2008) Beberapa faktor yang memepengaruhi Earnings Response Coefficient (ERC). Simposium Nasional Akuntansi (SNA) ke XI, Pontianak.

Moradi,Mehdi.Salehi, Mahdi. Erfanian, Zakiheh. (2010) A Study of Financial Leverage on ERC Throught Out Income Approach: Iranian Evidance. IRABF, 2010, Vol 2. No.2 page 104116.

Naimah, Zahroh, Sidharta Utama. (2006) Pengaruh ukuran perusahaan, pertumbuhan laba dan profitabilitas perusahaan terhadap Earnings Response Coefficient Dan koefisient respon nilai buku ekuitas. Simposium Nasional IX

Paramita, Ratna. (2011) Pengaruh leverage dan size terhadap Earnings Response Coefficient dengan voluntary disclousure sebagai variabel intervening. Jurnal Manajemen dan Akuntansi: 1-15.

Scott, William R., (2010) Financial Accounting Theory. Second edition. Canada: PrenticeHall. 
Susilowati, Christine,. (2008) Faktor-faktor penentu ERC. Jurnal Ilmiah akuntansi Vol.7, November 2008 hlm 146-161.

Teets, W.R. dan C.E. Wasley. 1996. Estimating Earning Response Coefficients: Pooled versus Firm Specific Models. Journal of Accounting and Economics. 21, 279-295

Widiastuti, Harjanti,. (2002) Pengaruh Luas Ungkapan Sukarela Terhadap Reaksi Investor. Simposium Nasional Akuntansi VI: 1314-1326.

(2002) Pengaruh Luas Ungkapan Sukarela Dalam Laporan Tahunan Terhadap Earnings Response Coefficient (ERC). SNA 5, Surabaya. hlm 74-86.

Widiastuti, Harjanti, 2002. Pengaruh Luas Ungkapan Sukarela Terhadap Reaksi Investor. Simposium Nasional Akuntansi VI: 1314-1326. 